\title{
The Effect of Revenue Sharing Fund on Economic Growth and Income Disparity (Case Study of District / City in East Kalimantan Province)
}

\author{
Yunus Sading $^{1} \quad$ Maryunani $^{2} \quad$ Candra Fajri Ananda $^{2} \quad$ Moh. Khusaini $^{2}$ \\ 1.Faculty of Economics and Business, Tadulako University, Indonesia \\ 2.Faculty of Economics and Business, Brawijaya University, Indonesia
}

\begin{abstract}
This study aims to examine, test and analyzing empirically: (1) direct effect of revenue sharing fund on expenditure structure; (2) direct and indirect effect of revenue sharing fund on income disparity and economic growth; (3) direct effect of expenditure structure on income disparities; and (4) direct and indirect effect of expenditure structure on economic growth. This study used pooled-data of 14 district / city in East Kalimantan Province for 2004-2011 periods. The analysis model used is Structural Modelling Analysis. The study results show that: (1) revenue sharing fund (DBH) directly have a negative and significant effect on expenditure structure; (2) revenue sharing fund $(\mathrm{DBH})$ have a direct negative and indirect positive effect on income disparities and negative but insignificant on economic growth; (3) expenditure structure has a direct negative effect on income disparity and positive but insignificant effect on economic growth; (4) income disparity has a significant and positive effect on economic growth.
\end{abstract}

Keywords: revenue sharing fund, expenditure structure, economic growth, income disparity.

DOI: $10.7176 / \mathrm{JESD} / 10-14-14$

Publication date:July $31^{\text {st }} 2020$

\section{INTRODUCTION}

There are various implications the implementation of Local Autonomy based on Law Number 32 Year 2004 on Local Government and Law Number 33 Year 2004 on Fiscal Balance between the Central and Local Governments, to put districts / cities as the focus of local autonomy. The district / city are not only faces the problem of autonomy related to decentralization for authority implementation of government and development, but also faces the problem of decentralization in development financing.

Implementation of district / city development planning in local autonomy era should accommodate various weaknesses of planning approach of previous era of centralization, by involving all components of community development. But on other hand, consequences of financing also need public participation, ability of local government apparatus, availability of infrastructure to support more local income to improve development financing optimally.

The local autonomy aims to increase economic growth and reduce local disparities and strongly affected by local macroeconomic conditions (Waluyo, 2007). The matching grant policy to regions is aimed to strengthen the local fiscal conditions and reducing local imbalances (horizontal imbalances) while at same time reducing the vertical imbalances between the center and regions.

Local revenue (PAD) is important factor to create local independence within local autonomy framework. However, the reality shows that PAD is only able to finance local government Expenditure at a maximum of $20 \%$ (Kuncoro, 2004). Data published by Central Statistics Agency show that of PAD contribution to total district / city revenue in Indonesia is less than $7.5 \%$ but the contribution matching grant to all district / city revenue in Indonesia reaches more than $70 \%$.

The PAD of East Kalimantan Province for 2004-2011 periods showed higher contribution to total district / city revenue in East Kalimantan Province, although fluctuating. The PAD contribution to total district / city revenue in 2004 was $4.45 \%$ and increased to $4.82 \%$ for 2011 .

Fiscal decentralization in the implementation relates with mechanism of fund allocation represented through financial balance in revenue sharing fund $(\mathrm{DBH})$, general allocation fund (DAU) and special allocation fund (DAK). The matching grant component, especially $\mathrm{DBH}$, is still being debated, both from fairness and proportionality aspect. Apart from debate, most important thing is how the regions can allocate the DBH as a driver of local economic growth to converge the per capita income and decomposition of inequality between regions.

DBH as one component of local development financing aims to increase local economic growth and reduce disparities between districts / cities caused by differences in potential and ownership of natural resources between regions. Therefore, this study put $\mathrm{DBH}$ as a dependent variable that will affect economic growth (PE) and income disparity (DPEN) as a dependent variable through the expenditure structure variable (SB). 


\section{LITERATURE REVIEW}

\subsection{Fiscal Decentralization, expenditure structure and Economic Growth}

The paradigm changes of central government to encourage development acceleration and improving public services in a fair and equitable way to whole community creates a policy shift from centralization to decentralization.

One important aspect related to fiscal decentralization at local level is allocation policy. Fiscal decentralization has a significant effect on various macroeconomic variables in region. Experts believe that fiscal decentralization will have a positive effect on growth, but theoretically the relationship between the two is still being debated. In fact, direct effect of fiscal decentralization on economic growth through allocation efficiency is also still being debated in theoretical and empirical literature (Khusaini, 2006).

Gupta et. al. (2005) found that composition of public expenditure that concentrated on wages tended to have low growth, while allocations on capital expenditure and non-wages showed faster output expansion. This study concludes that overall composition of public expenditure on more productive usage is very important to drive the economic growth.

Alesina and Perotti (1996) found that budget composition can explain the response of private sector to public policy which in turn has an effect on growth. If fiscal policy is applied to composition of expansive Expenditure, it will have a positive effect on economic growth.

Several studies explored the effect of expenditure composition on economic growth of a region. This study put expenditure composition as structure of expenditure despite differences in proxies. Easterly and Rebelo (1993), and Kneller, et al. (1999), Kneller (2000) found that investment in transportation and communication consistently correlated with growth in low-income countries. Furthermore, Nurudeen and Abullahi (2010), Cooray (2009), AlYousif (2000) and Abdullah (2000) concluded that expansion of government Expenditure positively promotes economic growth, through expenditure in health and education. Muhammed and Asfaw (2014) also found that expenditure composition in health and capital expenditure had positive and significant effect on economic growth in Ethopia.

Akai and Sakata (2002) found that Fiscal Decentralization measured by indicators of income and production had a significant positive effect on economic growth in United States, while the autonomy indicators did not show a significant effect. A study conducted by Shah (2006) using the same method, found that Fiscal Decentralization improve the macro economy of 40 countries. Wibowo (2008) found that decentralization had a positive effect on local development in Indonesia during the period 1999-2004. This study results theoretically reinforce the economic reasons of fiscal decentralization to improve the efficiency of public goods supply to ultimately drive economic growth (Oates, 1993; Martinez-Vazquez and McNab, 2003). Davoodi and Zou (1998) showed that fiscal decentralization had a negative and significant effect on economic growth in developing countries during the 19701989 periods. This finding was supported by Baskaran and Feld (2009) that fiscal decentralization negative affect on economic growth, but insignificant.

The findings of previous study confirm that the effects of fiscal decentralization depend on expenditure structures design for local governments decisions based on objective conditions of their respective regions, so that expenditure allocation policies appear to be more important to affect on economic growth than the decentralization size as reflected in nominal amount of the budget.

\subsection{Fiscal Decentralization and income disparity}

Fiscal decentralization is expected to improve efficiency in resource allocation. Local governments tend to have accurate information about the needs and preferences of people in their area. The application of fiscal decentralization in addition to encourage local economic growth is to reduce income disparities between regions. The government expenditure instruments must function to reduce local disparities.

The Kwon and Spilimbergo study (2005) in Russia found evidence that federal government expenditure reduce the level of local inequality. Adversely, Tselios, et. al. (2011) found indications that greater fiscal decentralization in Europe had contributed to reduce inequality among people in a region, even though as income rose, its contribution to reduce inequality was reduced.

Rodriguez-Pose and Ezcurra (2010) found the effect of fiscal decentralization on inequality depends on level of inequality and fiscal capacity. Te local gap in developed countries are lower than in developing countries. This shows that local government role to reduce inequality is very important, because the government has distributive functions.

Lewis (2001) and Hoftman, et. al. (2002) analyzed the relationship between fiscal decentralization and income distribution in Indonesian. They found that General Allocation Fund (DAU) as a proxy for fiscal decentralization reduces inequality. Different study by Resosudarmo and Vidyattama (2006) found that disparities between regions in Indonesia were still severe after fiscal decentralization between the periods of 1993 and 2002. The same study by Aritenang (2010) and Hartono and Irawan (2008) found that decentralization encourages positive growth for all provinces except Papua, but does not have much effect to reduce inequality. 
Another study by Savitri (2012) using revenue sharing fund proxy as fiscal decentralization and Gini Ratio as a proxy for inequality found that fiscal decentralization had a positive and significant effect on income inequality. It means that large fiscal decentralization tended to increase income inequality. Therefore, fiscal decentralization in local government policies has consequences on distributive function as reflected by income inequality (Savitri, 2012; Beramendi, 2003; and Martinez-Vasquez, 2010).

\section{METHODS, DATA AND ANALYSIS MODELS}

\subsection{Research methods}

This study uses a positive approach, using secondary data that published officially. The research type is explanatory research to explore measure and test the causality relationship between variables. This method is also suitable for research that aims to test hypotheses about the causal relationship between various variables studied based on data obtained to obtain conclusions and implications systematically. Hypothesis testing is done to strengthen the theory used as a basis for thinking in solving research problems.

The nature of study is verification to examine the effect of exogenous variables on endogenous variables, both directly and indirectly through mediation variable. Statistical test is done to get a conclusion and research implications, both theoretically and for policy.

\subsection{Data Types and Sources}

The secondary data of this research is officially published by Central Statistics Agency (BPS), Ministry of Finance, Ministry of Development Planning Agency, consists of:

- Gross Regional Domestic Product (GRDP) excluding oil and gas based on a constant price of 2000 districts / cities in East Kalimantan Province for period 2004-2011.

- Revenue sharing fund (DBH) and Tax revenue sharing fund (BHP) and Non-Tax / natural resource revenue sharing (BPSDA), according to districts / cities in East Kalimantan Province for 2004-2011 periods.

- District / City Government Financial Statistics for 2003-2012.

- Midyear population by district / city in East Kalimantan Province during the period 2004-2011.

\subsection{Analysis Model}

The quantitative analysis uses panel data (pooled data) as a combination of time series data and cross-section data. The DBH variable is measured by the ratio between Capital Expenditures and revenue sharing fund, while the Structure Expenditure variable is measured by ratio between Direct Expenditures and Capital Expenditures. The measurement of local economic growth variables is used as a real Gross Local Domestic Product (GRDP) based on constant 2000 prices, excluding oil and gas.

The Path Analysis is used to estimate the effect of revenue sharing fund (DBH). This path analysis technique is used to test the contribution of path coefficient on each path diagram of causal relationship between exogenous variables to endogenous variables (Riduwan and Kuncoro, 2011).

DBH is treated as an exogenous variable to estimate the partial or simultaneous effect, directly or indirectly with other variables. The expenditure structure (SB) and economic growth (PE) variables have multiple functions, namely as an intervening variable and an exogenous variable. The income disparity variable (DPEN) is treated as an endogenous variable.

Configuration of indirect effect of exogenous variables on endogenous variables mediated $b$ mediation variable will serve to clarify the relationship between exogenous and endogenous variables (MacKinnon, 2008). Mediation variables or intervening variables mediates variables relationship between explanatory variables to dependent variables.

The equation for the relationship between endogenous variables and exogenous variables are below.

1. Equations to test the direct relationship of DBH (X1) variable to SB (Y1), DPEN (Y2), and PE (Y3) variables, respectively:

Where:

$$
Y_{i}=\rho_{Y i X 1} X_{1}+\rho Y i \varepsilon \varepsilon
$$

$\mathrm{Yi}=$ mediation variable, $\mathrm{i}=1,2$ and 3

$\mathrm{X} 1=$ revenue sharing fund (exogenous variable)

$\rho=$ path coefficient between variables

$\varepsilon i=$ Error (error)

2. The equation to test the relationship of $\mathrm{DBH}(\mathrm{X} 1)$ variable to $\mathrm{PE}(\mathrm{Y} 2)$ variable, through the mediation variable $\mathrm{SB}(\mathrm{Y} 1)$, is:

$\mathrm{Y} 2=\rho \mathrm{Y} 2 \mathrm{X} 1 \mathrm{X} 1+\rho \mathrm{Y} 2 \mathrm{Y} 1 \mathrm{Y} 1+\rho \mathrm{Y} 2 \varepsilon \varepsilon 3$

3. The equation to test the relationship of $\mathrm{DBH}(\mathrm{X} 1)$ variable to $\mathrm{PE}(\mathrm{Y} 3)$ variable, through the mediation variables SB (Y1) and DPEN (Y2) is below. 


$$
Y_{2}=\rho_{Y 2 X 1} X_{1}+\rho_{Y 2 Y 1} Y_{1}+\rho_{Y 2 \varepsilon} \varepsilon 3
$$

\section{RESULTS}

\subsection{Hypothesis testing}

Hypothesis testing is done on structural model completely and classified by forming several sub-structures of model to describe the relationship between variables to measure the direct and indirect effects. The path coefficients of each variable are analyzed through statistical tests partially and simultaneously.

Partial test (t-test) examines effects of a variable to others to test hypothesis with 2-tailed and based on substructure path. Overall structure model is divided into 3 sub-structures and each sub-structure consists of 1 model. The result is shown in table 1.

Table 1. Testing the Significance of Effect Between Variable Sub-Structure Models

\begin{tabular}{|c|c|c|c|c|}
\hline Effect Between Variables & Path Coefficients & $\mathbf{T}_{\text {count }}$ & Decision & Description \\
\hline \multicolumn{5}{|c|}{ Model of Sub Structure 1} \\
\hline DBH on SB & -0.3394 & -3.6969 & $\mathrm{H}_{0}$ : Rejected & Significant $* * *$ \\
\hline \multicolumn{5}{|c|}{$\begin{array}{l}\text { Coefficient of other variables (the rest) }=0.8848 \text { or } 88.48 \% \\
\text { Determination Coefficient }\left(\mathrm{R}^{2}\right)=0.1152 \text { or } 11.52 \% \\
\mathrm{t}_{\text {table }(0.01)}=2.617\end{array}$} \\
\hline \multicolumn{5}{|c|}{ Model of Sub Structure 2} \\
\hline DBH on DPEN & -0.0544 & -0.5282 & $\mathrm{H}_{0}:$ Accepted & Insignificant \\
\hline SB on DPEN & -0.1293 & -1.2558 & $\mathrm{H}_{0}:$ Accepted & Insignificant \\
\hline \multicolumn{5}{|c|}{$\begin{array}{l}\text { Coefficient of other variables }(\text { the rest })=0.9851 \text { or } 98.51 \% \\
\text { Determination Coefficient }\left(\mathrm{R}^{2}\right)=0.0149 \text { or } 1.49 \% \\
\mathrm{~F}_{\text {table }(0.05 ; 2 ; 104)}=3.0837 ; \mathrm{t}_{\text {table }(0.05)}=1.983 \text { and } \mathrm{F}_{\text {count }}=0.7865 \rightarrow \mathrm{p}=0.458\end{array}$} \\
\hline \multicolumn{5}{|c|}{ Model of Sub Structure 3} \\
\hline DBH on PE & -0.0043 & -0.0419 & $\mathrm{H}_{0}:$ Accepted & Insignificant \\
\hline SB on PE & 0.0202 & 0.1970 & $\mathrm{H}_{0}:$ Accepted & Insignificant \\
\hline DPEN on PE & 0.1963 & 2.0358 & $\mathrm{H}_{0}$ : Rejected & Significant $* *$ \\
\hline \multicolumn{5}{|c|}{$\begin{array}{l}\text { Coefficient of other variables }(\text { the rest })=0.9618 \text { or } 96.18 \% \\
\text { Determination Coefficient }\left(\mathrm{R}^{2}\right)\left(\mathrm{R}^{2}\right)=0.0382 \text { or } 3.82 \% \\
\mathrm{~F}_{\text {table }(0.05 ; 3 ; 103)}=2.6928 ; \mathrm{t}_{\text {table }(0.05)}=1.983 \text { and } \mathrm{F}_{\text {count }}=1.362 \rightarrow \mathrm{p}=0.261\end{array}$} \\
\hline \multicolumn{5}{|c|}{$\begin{array}{l}* * \text { Significant at } 95 \% \text { level }(\alpha=0.05) \\
* * * \text { Significant at } 99 \% \text { level }(\alpha=0.01)\end{array}$} \\
\hline
\end{tabular}

Source: Research Data Processing Results

The test results for the significance level of variables relationship can be explained below.

1. There are 4 effects between variables that statistically insignificant, indicated by $t_{\text {count }}<t_{\text {table }}=1.983$, at error rate $(\alpha=0.05)$ or the significance level of $95 \%$, namely:

a. Effect of DBH on income disparity $\left(\mathrm{t}_{\text {count }}=-0.5282\right)$;

b. Effect of DBH on economic growth $\left(\mathrm{t}_{\text {count }}=-0.0419\right)$;

c. The Effect of SB on income disparity $\left(t_{\text {count }}=-1,2558\right)$;

d. The Effect of SB on economic growth $\left(\mathrm{t}_{\text {count }}=0.1970\right)$;

2. There are 2 effects that are not consistent with initial prediction, namely:

a. The relationship between revenue sharing fund and economic growth show negative path coefficient (0.0419 ).

b. The relationship between economic growth and income disparity shows positive path coefficient $(0.1963)$.

3. There are 2 effects between variables that are statistically significant, indicated by $t_{\text {count }}>t_{\text {table }}=1.983$, at a significance level of $95 \%(\alpha=0.05)$, namely:

a. Effect of DBH on SB ( $\left.t_{\text {count }}=-3.6969\right)$;

b. Effect of DPEN on PE $\left(\mathrm{t}_{\text {count }}=2.0358\right)$;

\subsection{Goodness of Fit Model}

Goodness of fit test evaluates the compatibility level or Goodness of Fit (GOF) between the data and model. GOF of a structural model assessment cannot be done directly. The structural model does not have the best statistical test that can explain predictive "strength" of model, so several GOF measurements have been developed that can be used together. This led to debate and controversy (Bollen and Long, 1993).

Capital fit test contains two important things, namely: First is overall model fit test. This test is closely related to generalization the model parameters to population, using the GFT (Goodness of Fit Test) measure. Model fit test means "no difference" between the parameter covariance matrix and statistical covariance matrix.

The test results absolutely meet the model fit criteria, with a probability value (p) of Chi-square $\left(\chi^{2}\right)$ of $0.7611>$ 
$0.05(\mathrm{p} \geq 0.05)$, RMSEA value of 0.0000 (RMSEA $\leq 0.08)$ with degrees of freedom $(\mathrm{df})=1$. Incremental test is indicated by estimated AGFI value of $0.9948>0.90$ (AGFI $\geq 0.90)$ and CFI value of $1.0000>0.90(\mathrm{CFI} \geq 0,90)$ and other GOF measurements as a whole fulfil the model's fit criteria. It can be concluded that overall results of GOF evaluation shows model fit with data to estimate the relationship between DBH, SB, DPEN and PE. The estimation results from model have a good level of validity.

\section{DISCUSSION}

\subsection{The Effect of Revenue Sharing Fund on Income Disparity}

The effect of revenue sharing fund and expenditure structure on income disparity is shown by income disparity model (Sub-Structure 2 Model 1). The test results show that two variables simultaneously have no significant effect on income disparity. The hypothesis test for partial test showed that revenue sharing fund has a negative and insignificant effect on income disparity at $95 \%$ confidence level.

This finding confirms that fiscal decentralization with revenue sharing fund proxy has a direct but insignificant effect to decrease in revenue disparity between districts / cities in East Kalimantan Province for 20042011 periods. Although the effect of $\mathrm{DBH}$ is insignificant, relationship between revenue sharing funds (DBH) and income disparity (DPEN) is negative. It means that higher the $\mathrm{DBH} / \mathrm{BM}$ ratio will cause a decrease in income disparity. The increasing of DBH / BM ratio illustrates that revenue sharing fund (DBH) increases is higher than Capital Expenditure (BM). The higher revenue sharing fund (DBH) than Capital Expenditure (BM) indicates that majority of revenue sharing fund increase is not allocated to Capital Expenditure (BM) but to other expenditures outside of Capital Expenditures.

The ratio between DBH and BM will illustrate the change in Capital Expenditures due to changes in revenue sharing fund, the ratio between the two decreases if the change in Capital Expenditure is higher than the change in revenue sharing fund. This study findings support previous research of Rodriquez-Pose and Ezcurra (2010) and Prud'homme (1995) that fiscal decentralization has negative relationship with local disparities in developing countries. Akai and Sakata (2002) found that autonomy in fiscal decentralization has a negative effect on inequality between regions, Gil Canaleta, et. al. (2004) also found a negative relationship between fiscal decentralization and local disparities in developed countries.

Adversely, Savitri study (2012) found that fiscal decentralization with DBH proxy has a positive and significant effect on income inequality with Gini coefficient proxy. This indicates that high fiscal decentralization tends to increase proxy inequality.

The implication is the expenditure structure should become an important instrument for local governments to determine the local expenditure allocation policies. It should consistent with development goals and priorities of each region in order to achieve the efficiency in providing optimal public services.

Higher fiscal decentralization will be more beneficial for regions that have greater economic potential than regions with less economic potential. Rich regions use fiscal decentralization to use local expenditure efficiently to develop this potential as a driver of economic growth through the policy of expenditure allocation to productive sectors. Adversely, relatively poor regions have a tendency to allocate fund to less productive expenditure, although this trend still needs a deeper study.

The revenue source from revenue sharing fund should be used as an instrument to improve public services, especially after the government implements a policy of decentralization and wider local autonomy to districts / cities. Therefore, revenue sharing fund as a component of matching grant has a strategic position to fill fiscal gap or fiscal deficit caused by low local revenue on one hand. On other hand the larger funds is needed to execute the authority from central government to local government.

\subsection{The Effect of Revenue Sharing Fund on Economic Growth}

Hypothesis test for economic growth model shows that simultaneously, revenue sharing fund, expenditure structure and income disparity have no significant effect on economic growth at a $95 \%$ confidence level. The hypothesis test results through partial tests indicate that revenue sharing fund has a negative and insignificant effect on economic growth at a $95 \%$ confidence level.

This finding confirms that decentralization with revenue sharing fund proxy has insignificant direct effect to increase economic growth at district / city areas in East Kalimantan Province for 2004-2011 periods. The hypothesis results implicitly show that revenue sharing fund does not affect on economic growth in studied area.

This finding illustrate the sensitivity of direct effect of revenue sharing fund on economic growth is relatively weak. Hypothesis test results indicate that expenditure structure has a positive but insignificant effect on economic growth. It means that an increase in ratio of direct expenditure to capital expenditure to reflect expenditures structure will reduce the level of economic growth in each district / city.

This test results provide an indication that composition of local expenditure allocated in form of Capital Expenditures has not been effective to promote economic growth. This is very possible because the budgeting policy has not been efficient, namely budget allocation is more dominant in unproductive sectors as a determinant 
of local economic growth. This study, although the relationship direction between the Structure of Expenditure and economic growth is positive, but there is no significant empirical evidence to explain that both capital expenditure and direct expenditures encourage the economic growth of each district / city in East Kalimantan Province for 2004- 2011 period.

Inefficiency in public sector should not occurred, because it will cause counterproductive to economic growth, even if viewed from characteristics of public goods are non excludable and non-valid. It has implications for market mechanisms that do not necessarily provide efficient pareto solutions for allocation of public goods supply (see: Gruber, 2007; Rosen and Gayer, 2008).

The structure of local expenditure becomes important, when public resources are limited. The government has budget constraints and considering the benefits of one type of expenditure with another type of expenditure. Some literature generally predicts that productive expenditure will have a positive effect on long-term growth and unproductive expenditure will have a negative effect (Barro, 1991).

The empirical argument seems to confirm that decentralization of expenditure through allocation of government expenditure have an effect on growth, although the direction of effect and the significance still causes debate.

Several previous studies have found a directional relationship that supports this research, although with different levels of significance. The study of Zhang and Zou (1998), found a significant negative effect of fiscal decentralization on economic growth in developing countries. Afonso and Furceri (2010) also found that public expenditure has negative and significant effect on economic growth (measured real GDP per capita growth). This shows an inconsistency between economic theory and empirical evidence.

Barro and Salai-i-Martin (1992); Fisher (1993) and Lopez (2004) found that government Expenditure has a negative effect on economic growth. The theoretical argument was the larger role and government intervention in economy tend to distort the market, which in turn will worsen the economic growth. The study results are contradictory to this study, Lin and Liu (2000); Akai and Sakata (2002); and Carrion, et al. (2008) who found a positive relationship between fiscal decentralization and economic growth.

The weak effect of revenue sharing fund on economic growth is related to effectiveness of budget allocation policies to non-productive allocations. The available data shows that DBH received by each district / city can accelerate the provision of adequate public service facilities and infrastructure, local governments budgeting still tend to be oriented to indirect expenditure (employee salaries, wages, honorarium, official travel and other apparatus expenditure) which tends to increase faster than the increase in capital expenditure. DBH cannot play an optimal role as an instrument to provide public goods in accordance with local preferences as a goal of decentralization and local autonomy.

The low allocation of capital expenditure causes the need to increase educational facilities and infrastructure and health services. It makes the quality of human resources does not increase significantly. The provision and improvement of infrastructure should increase accessibility in productive businesses, which theoretically and empirically can drive economic growth.

The high goods and services expenditures indicate the tendency of district / city governments to invest in short term. In fact, it plays a relatively lower role to provide physical infrastructure and other public goods, so the effect on local economic activities at macro level is also low.

\subsection{Effect of Income Disparity on Economic Growth}

The effect of income disparity on economic growth is shown by economic growth model (Sub-Structure 3 Model 1). This model uses three independent (exogenous) variables of revenue sharing fund, expenditure structure and income disparity. Simultaneous test results indicate that all three variables have no significant effect on economic growth. The partial hypothesis test results show that income disparity has a positive and significant effect on economic growth, with coefficient of 0.1963 .

This test results confirm that higher inequality it will increase the economic growth in each district / city in East Kalimantan Province for 2004-2011 period. This is inconsistent with initial prediction hypothesized that inequality in per capita GRDP would negatively affect on economic growth in each region.

Theoretical arguments and some previous empirical estimation provide contradictory conclusions, whether the distribution of income (inequality) benefits the economic performance of a country / region or actually becomes an obstacle to economic growth.

Some previous findings that support the results of this study include Forbes (2000) to conclude that in short and medium term, inequality (measured by Gini ratio) positively and significantly affects on economic growth. Garbis (2005), confirmed Forbes's findings and also found a positive and statistically significant effect of inequality and growth, while Charles-Coll (2013) found a positive relationship between inequality and growth in long term.

Positive relationship between income disparity and economic growth in this study findings contradicts with some previous studies, such as Perotti (1993); Persson and Tablelini (1994); Alesina and Rodrik (1994); Clarke 
(1995); Birdsall, et. al. (1995); Alesina and Perotti (1996).

Galor and Moav (2004) stated that in endogenous growth model, replacement of physical capital accumulation into accumulation of human capital as an engine of growth has changed the effect of disparity on growth. This opinion justifies that a transition process occurs in determinants of economic growth. It means that determinants of economic growth are not solely driven by ability of a country / region to accumulate capital, but the role of human capital is important as a driving factor in economic growth. This also strengthens the theoretical argument, that endogenous growth model can be accepted as a broad model in analysis of economic growth.

Bengoa and Sanchez-Robles (2005) tested a sample of middle and high-income countries (developed countries). The results of his study concluded that in middle-income countries the relationship between inequality and growth was inconsistent (ambiguous), but in developed countries found a positive and statistically significant relationship. They conclude that effect of inequality on growth seems to differ based on development stage of a country. In addition to above findings, several studies also found no correlation between income disparity and economic growth, for example Roemer and Lee (1998); Castelló and Domenech (2002); Panizza (2002).

\subsection{Research Limitations}

This study limitation is DBH indicator to measure the fiscal decentralization and measurement of income disparity can use additional variables that can identify inequalities in regions that are the domain of local governments in setting budget allocation policies orient to reduce income disparity, ie using the Gini Ratio as an indicator measurement of income disparity, as a comparison.

\section{CONCLUSIONS AND SUGGESTIONS}

\subsection{Conclusion}

Based on hypothesis testing and analysis results, the conclusions are stated below.

1. Revenue sharing fund as the implementation of fiscal decentralization only functions to reduce fiscal imbalance between regions (horizontal imbalance) and between the center and regions (vertical imbalance) but has no significant effect on income disparity and economic growth. This shows that local budget allocation policy is more oriented to government consumption expenditure (salary and other employee expenditure) than government investment expenditure (capital expenditure and goods), which can encourage economic growth and reduce income disparity.

2. The effectiveness of revenue sharing fund is not solely determined in quantity, but its effect on disparity of revenues and economic growth depends on budget allocation reflected in local expenditure structure. This shows that local government budget allocation structure has not been able to stimulate private investment, and even tends to have a bad effect (crowding-out effect) on private investment.

3. The positive and significant effect of income disparity on economic growth has implications for process of "trade off" between economic growth and income disparity.

\subsection{Suggestion}

The government needs to comprehensively review efficient budget allocation policies to encourage economic growth and enhance human development, especially in terms of providing infrastructure, increasing investment in education and health sectors.

\section{REFERENCES}

Abdullah H.A, 2000. The Relationship Between Government Expenditure and Economic Growth in Saudi Arabia. Journal of Administrative Science, 12(2): 173-191.

Afonso, Antonio dan Furceri, Davide. 2010. Government Size Composition, Volatility and Economic Growth. European Journal of Political Economy, $26 \quad$ (4): 517-532. 29 Oktober 2010. http://papers.ssrn.com/sol3/papers.cfm

Akai, Nobuo dan Sakata, Mayaso. 2002. Fiscal Decentralization Contributes to Economic Growth: Evidence from State Level Cross Section Data for United States. Journal of Urban Economics Vol. 52: 93-108.

Alesina, Alberto.dan Roberto Perotti. 1996. Income Distribution, Political Instability, and Investment, European Economic Review, 40(6): 1203-1228. Elsevier. https://doi.org/ 10.1016/0014-2921(95)00030-5

Alesina, Alberto dan Dani Rodrik. 1994. Distributive Politics and Economic Growth, Quarterly Journal of Economics, 109 (2): 465-490. http://www.jstor.org/stable/ 2118470

Al-Yousif Y, 2000. Does Government Expenditure Inhibit or Promote Economic Growth: Some Empirical Evidence from Saudi Arabia. Indian Economic Journal, 48(2).

Aritenang, Adiwan Fahlan. 2010. A Study on Indonesia Regions Disparity: Post Decentralization. MPRA Paper 25245, University Library of Munich, Germany. http://mpra.ub.uni-muenchen.de/25245/

Barro, Robert J. 1991. Economic Growth in a Cross Section of Countries. The Quarterly Journal of Economics, Vol. 106, No. 2: 407-443. http://links.jstor.org/sici......C 
Barro, Robert J dan Xavier Sala-i-Martin. 1992. Publik Finance in Models of Economic Growth. Review of Economic Studies 54 (201). www.columbia. edu/ xs23/papers/.../publicfn.pdf

Baskaran, Thushyanthan dan Lars P. Feld. 2009. Fiscal Decentralization and Economic Growth in OECD Countries: Is there a Relationship? CESifo Working Paper No. 2721. July 2009. http://www.cesifogroup.de/.../WP/Papers/.../wp-cesifo-2009-07/ cesifo1 wp2721.pdf

Bengoa, Marta dan Sanchez-Robles, Blanca. 2005. Policy Shocks as a Source of Endogenous Growth. Journal of Policy Modelling, 27: 249-261. Elsevier.

Beramendi, Pablo. 2003. Political Institutions and Income Inequality: The Case of Decentralization. Discussion $\begin{array}{llll}\text { Paper SP II 2003-09, Wissenschaftszen-trum } & \text { Berlin, }\end{array}$ http://econstor.eu/bitstream/10419/51220/1/376523581.pdf

Birdsall, Nancy, David Ross dan Richard Sabot. 1995. Inequality and Growth Reconsidered: Lessons from East Asia. World Bank Economic Review, Vol. 9 (3): 477-508.

Bollen, Kenneth. A dan J. Scott Long (Editors). 1993. Testing Structural Equation Models (SEM). California, London, New Delhi:Sage Publication Inc.

Carrion-i-Silvestre, Josep Lluis, Marta Espasa, and Toni Mora. 2008. Fiscal Decentralization and Economic Growth in Spain. Public Finance Review 36 (2): 194-218.

Castelló, Amparo dan Doménech, Rafael. 2002. Human Capital Inequality and Economic Growth: Some New Evidence. The Economic Journal. Volume 112 (478): C187-C200. https://doi. org/10.1111/1468-0297.00024.

Charles-Coll, Jorge Alberto. 2013. The Debate Over the Relationship Between Income Inequality and Economic Growth: Does Inequality Matter for Growth? Research in Applied Economics. Vol. 5 No.2.

Clarke, G.R.G.P. 1995. More Evidence on Income Distribution and Growth, Journal of Development Economics, 47(2): 403-427. http://dx.doi.org/10.1016/0304-3878(94)00069-O

Cooray, Arusha. 2009. Government Expenditure, Governance and Economic Growth. Comparative Economic Studies, Volume 51(3): 401-418. http://www.ingentacon-nect.com/.../pal/ces; jsessionid=qlg8lgkzfvms.alice

Davoodi, Hamid dan Heng-fu Zou. 1998. Fiscal Decentralization and Economic Growth: A Cross Country Study. Journal of Urban Economics, No. 43 (2): 244-257.

Easterly, William dan Sergio Rebelo. 1993. Fiscal Policy and Economic Growth: An Empirical Investigation. NBER Working Papers No. 4499. http://www. nber.org/papers/w4499.pdf

Forbes, Kristin J. 2000. A Reassessment of the Relationship Between Inequality and Growth. American Economic Review 90 (4): 869-887. http://web.mit.edu/kjforbes/www/Papers/Inequality-Growth-AER.pdf

Garbis, Iradian. 2005. Inequality, Poverty and Growth: Cross-Country Evidence. International Monetary Fund WP/05/28. IMF Working Paper Middle East and Central Asia Department.

Gil Canaleta, Carlos., Pascual, Pedro and Rapún, Manuel. 2004. Regional Economic Disparities and Decentralisation. Urban Studies. 41: 71-95. https://doi.org/10.1080/....55696

Gupta, Sanjeev, Benedict Clements, Emanuele Baldacci, Carlos Mulas-Granados. 2005. Fiscal Policy, Expenditure Composition and Growth in Low-Income Countries. Journal of International Money and Finance, 24: 441-463. Elsevier. www.elsevier.com/locate/ econbase

Gruber, Jonathan. 2007. Public Finance and Public Policy. Second Edition. New York: Worth Publisher.

Hartono, Djoni dan Tony Irawan. 2008. Decentralization Policy and Equality: A Theil Analysis of Indonesian Income Inequality. Working Paper in Economics and Development Studies No. 200810. Departement of Economics, Padjadjaran University, Indonesia.

Hofman, Bert., Kadjatmiko dan Kaiser, Kai. 2002. Evaluating Indonesia's Fiscal Equalization. Word Bank Office, Jakarta.

Khusaini, Mohammad. 2006. Ekonomi Publik: Desentralisasi Fiskal dan Pembangunan Daerah. Cetakan Pertama, Malang: Badan Penerbit FE UNIBRAW.

Kuncoro, Mudrajat. 2004. Otonomi dan Pembangunan Daerah: Reformasi, Perencanaan, Strategi dan Peluang, Jakarta: Erlangga.

Kneller, Richard. 2000. The Implications of the Comprehensive Spending Review for the Long-Run Growth Rate: a View From the Literature. National Institute of Economic and Social Research, Vol. 171(1): 94-105.

Kneller, Richard, Michael F.Bleaney dan Norman Gemmell. 1999. Fiscal Policy and Growth: Evidence from OECD countries. Journal of Public Economics Volume 74 (2): 171-190. https://doi.org/10.1016/S00472727(99) 00022-5

Kwon, Goohoon dan Antonio Spilimbergo. 2005. Russia’s Regions: Income Volatility, Labor Mobility, and Fiscal Policy. IMF Working Paper WP/05/185. https://www.imf.org/external/ pubs/ft/wp/2005/wp05185.pdf

Lewis, Blane D. 2001. The New Indonesian Equalization Transfer. Bulletin of Indonesian Economic Studies 37 (3): $325-43$

Lin, Justin Yifu and Liu, Zhiqiang. 2000. Fiscal decentralization and economic growth in China. Economic Development and Cultural Change; Oct 2000; 49, 1; ABI/INFORM Global

López, Ramón. 2004. Effect of the Structure of Rural Public Expenditures on Agricultural Growth and Rural 
Poverty in Latin America. Inter-American Development Bank.

MacKinnon, David P. 2008. Introduction to Statistical Mediation Analysis. New York: Erlbaum.

Martinez-Varquez, Jorge dan McNab, Robert M. 2003. Fiscal Decentralization and Economic Growth. World Development 3: 1597-1616. I

Muhammed. A, dan Asfaw. M. 2014. Government Spending for Economic Growth in Ethiopia. Journal of Economics and Sustainable Development, 5(9): 66-74.

Nurudeen, Abu dan Usman, Abdullahi. 2010. Government Expenditure and Economic Growth in Nigeria, 1970 2008: A Disaggregated Analysis. Business and Economic Journal, Vol. 4 (3): 237330. http://astonjournals.com/bej

Oates, Wallace E. 1993. Fiscal Decentralization and Economi Development, National Tax Journal, 46 (2): 237 43.

Panizza, Ugo. 2002. Income Inequality and Economic Growth: Evidence from American Data. Journal of Economic Growth. Volume 7 (1): 25-41.

Perotti, Roberto. 1993. Political Equilibrium, Income Distribution and Economic Growth. Review of Economic Studies, 60 (4): 755-776. http://links.jstor.org/sici? sici=0034-...-X\&origin $=b c$

Persson, T dan Tabellini, G. 1994. Is Inequality Harmful for Growth. American Economic Review, 84 (3): 600 621.

Prud'homme, Remy. 1995. The Dangers of Decentralization. The World Bank Research Observer 10 (2): 201-220.

Resosudarmo, Budi P. dan Vidyattama, Yogi. 2006. Regional Income Disparity in Indonesia: A Panel Data Analysis. ASEAN Economic Bulletin Volume 23 (1): 31-44.

Riduwan dan Engkos Achmad Kuncoro. 2011. Cara Menggunakan dan Memakai Path Analysis (Analisis Jalur). Cetakan Ketiga. Bandung: Alfabeta.

Rodriguez-Pose, Andres dan Ezcurra, Roberto. 2010. Does Decentralization Matter for Regional Disparities ? A Cross-Country Analysis. Journal of Economic Geography 10 (2010). Oxford University Press.

Roemer, John dan Lee, Woojin. (1998). Income Distribution, Redistributive Politics, and Economic Growth. Journal of Economic Growth. 3: 217-40. 10.1023/A:1009762720862.

Rosen, Harvey S., dan Gayer, Ted. 2008. Public Finance. Eight Edition. New York: McGraw-Hill.

Savitri, Mariana Dyah. 2012. The Impact Of Fiscal Decentralization on Income Inequality in Indonesia. The Okuma School of Public Management. http://www.waseda-pse.jp/file/File/kouken/e-kiyou/THE

Shah, Anwar. 2006. Fiscal Decentralization and Macroeconomic Management. International Tax and Public Finance 13: 437-462.

Tselios, Vassilis, Rodriguez-Pose, A., Pike, Andy, Tomaney, John dan Torrisi, Gianpierro. 2011. Income Inequality, Decentralization and Regional Development in Western Europe. Working Papers Series in Economics and Social Sciences 2011/16. Imdea Institute of Social Sciences.

Waluyo, Joko. 2007. Dampak Desenralisasi Fiskal Terhadap Pertumbuhan Eknomi dan Ketimpangan Pendapatan Antardaerah di Indonesia, Parallel Session IA: Fiscal Decentralization, 12 Desember 2007.

Wibowo, Puji. 2008. Mencermati Dampak Desentralisasi Fiskal Terhadap Pertumbuhan Ekonomi Daerah. Journal Keuangan Publik, Vol. 5, No. 1, Oktober 2008.

Zhang, Tao dan Heng-fu Zou. 1998. Fiscal Decentralization, Public Spending, and Economic Growth in China. Journal of Public Economics 67: 221-240, Elsevier. 